Cahiers $d u$ MONDE RUSSE

\section{Cahiers du monde russe}

Russie - Empire russe - Union soviétique et États indépendants

46/1-2 | 2005

La Russie vers 1550

\title{
Culture and politics, or the curious absence of Muscovite state building in current American historical writing
}

Valerie A. KIVELSON

\section{OpenEdition}

1 Journals

Édition électronique

URL : https://journals.openedition.org/monderusse/8771

DOI : 10.4000/monderusse.8771

ISSN : $1777-5388$

Éditeur

Éditions de l'EHESS

Édition imprimée

Date de publication : 1 janvier 2005

Pagination : $19-28$

ISBN : 2-7132-2055-6

ISSN : $1252-6576$

Référence électronique

Valerie A. KIVELSON, « Culture and politics, or the curious absence of Muscovite state building in current American historical writing », Cahiers du monde russe [En ligne], 46/1-2 | 2005, mis en ligne le 01 janvier 2007, consulté le 04 septembre 2022. URL : http://journals.openedition.org/monderusse/ 8771 ; DOl : https://doi.org/10.4000/monderusse.8771 
chercher : repérer : avancer

Cet article est disponible en ligne à l'adresse :

http://www.cairn.info/article.php?ID REVUE=CMR\&ID NUMPUBLIE=CMR 461\&ID ARTICLE=CMR 4610019

Culture and politics, or the curious absence of Muscovite state building in current American historical writing

par Valerie A. KIVELSON

| Editions de l'EHESS | Cahiers du monde russe

2005/1-2 - Vol 46

ISSN 1252-6576 | ISBN 2713220556 | pages 19 à 28

Pour citer cet article :

-A. KIVELSON V., Culture and politics, or the curious absence of Muscovite state building in current American historical writing, Cahiers du monde russe 2005/ 1-2, Vol 46, p. 19-28.

Distribution électronique Cairn pour les Editions de l'EHESS.

(C) Editions de l'EHESS. Tous droits réservés pour tous pays.

La reproduction ou représentation de cet article, notamment par photocopie, n'est autorisée que dans les limites des conditions générales d'utilisation du site ou, le cas échéant, des conditions générales de la licence souscrite par votre établissement. Toute autre reproduction ou représentation, en tout ou partie, sous quelque forme et de quelque manière que ce soit, est interdite sauf accord préalable et écrit de l'éditeur, en dehors des cas prévus par la législation en vigueur en France. Il est précisé que son stockage dans une base de données est également interdit. 


\section{CULTURE AND POLITICS, OR THE CURIOUS ABSENCE OF MUSCOVITE STATE BUILDING IN CURRENT AMERICAN HISTORICAL WRITING}

The task assigned to me in this volume is to survey the present-day literature on the building of the Muscovite state in the fifteenth and first half of the sixteenth centuries. This turns out to be a difficult assignment because, as it happens, there is no such literature at the moment, or precious little of it. Thirty or forty years ago, one would have met a far richer array of works precisely on the topic at hand. In the 1960s and 1970s, North American scholars contributed important interpretations of the precipitous rise of a centralized state based in the former princely backwater of Moscow. With an eye to tracking territorial expansion, institutional development, and rapid centralization of power and control, American scholars joined a broader community of historians interested in the formal, measurable rules, institutions, and powers of a growing monarchical state. A scholarly cohort including distinguished men such as Gustave Alef, Richard Pipes, Jaroslaw Pelenski, and George Vernadsky, mostly American by emigration rather than by birth, created the field of Early Russian Studies in America with their investigations of the fledgling Muscovite state. ${ }^{1}$ Today, however, despite a real florescence in American research

1. Gustave Alef, The Origins of Muscovite Autocracy: The Age of Ivan III, published as Forschungen zur osteuropäischen Geschichte, 39 (1986); and his Rulers and Nobles in Fifteenth-Century Muscovy (London: Variorum Reprints, 1983); Jaroslaw Pelenski, Russia and Kazan; Conquest and Imperial Ideology (1438-1560s) (The Hague: Mouton, 1974); Richard Pipes, Russia under the Old Regime (New York: Charles Scribner's Sons, 1974); George Vernadsky, Russia at the Dawn of the Modern Age (New Haven: Yale University Press, 1959). None of these listing claims any degree of completeness, and I apologize to those whose work I have omitted inadvertently or for reasons of space. I would like to thank Ronald Suny for his very helpful critical reading. 
and publication in Muscovite history, little work addresses specifically this nexus of issues within the given chronological limits. Strikingly absent are the topics that used to preoccupy historians. High politics, diplomacy, war, institutions, administration, and even class and social structure are all but invisible. Economics are scantily represented and invisible for the period of Moscow's early political consolidation. ${ }^{2}$ Although the state remains at the heart of most inquiries into the Muscovite past, by and large the focus of American Muscovite studies has shifted forward in time and more toward cultural than institutional or diplomatic questions. Rather than cataloguing who is doing what among American Muscovite historians, then, this survey will take up the provocation to explore and explain that shift in American research agendas. Why the striking absence of studies on early Muscovite state-building in current US historical work?

These two trends, topical and chronological shifts, are closely related. The very questions that tend to preoccupy historians in the US today are ones that make no sense for the earlier period because they address the particular nature of early modernity. Perhaps, in fact, thinking of the shift forward in Muscovite historical work reveals one of the fundamental characteristics of that elusive period we know as Early Modernity - the beginning of consensual, integrated national states. This exercise in thinking through the curious absence of work on early Muscovite stateformation in current American historiography may help us understand the ways in which our heuristic division of medieval and early modern periods reflect real and significant changes in the meaning of politics, the nature of rule, and the role of subjects in a polity. ${ }^{3}$

The sea change in American Muscovite studies reflects the general effects of the same grab bag of important theorists who affected the course of historical studies across the board. Antonio Gramsci's cultural Marxism inspired historians to study more closely the ways in which class power may be articulated through cultural means and the extent to which large segments of the population might absorb the premises and assumptions of the hegemonic classes. The translation of Jürgen Habermas's work on the "public sphere" offered English-speaking scholars another way of thinking about politics outside of a strictly institutional framework. Michel Foucault's interest in the diffuse, capillary workings of power wending and reproducing itself throughout society led historians to examine the quotidian workings and reproduction of power. Along somewhat similar lines, historians also

2. Jarmo Kotilaine is one of the few people working on economic topics at the present, although it was quite a popular topic twenty years ago. See for example, his "Mercantilism in Pre-Petrine Russia," in Jarmo Kotilaine and Marshall Poe, eds., Modernizing Muscovy: Reform and Social Change in Seventeenth-Century Russia (New York: Routledge, 2004): 433-460.

3. On the issue of early modernity in Russia, see Robert O. Crummey, "Muscovy and the 'General Crisis of the Seventeenth Century'," Journal of Early Modern History, 2 (1998): 156180; and "Seventeenth-Century Russia: Theories and Models," Forschungen zur osteuropäischen Geschichte, 56 (2000): 113-132; Jarmo Kotilaine and Marshall T. Poe, "Modernization in the Early Modern Context: The Case of Muscovy," in J. Kotilaine and M. Poe, eds., Modernizing Muscovy, op. cit.: 1-8; George B. Weickhardt, "Modernization of the Law in Seventeenth-Century Russia," in ibid.: 79-96. 
followed sociologist Norbert Elias's lead in appreciating the power of words, forms, manners, and conventions to constrain and confine behavior without direct institutional or coercive enforcement. Cultural anthropologists, particularly the widely read Clifford Geertz, offered other models for considering culture as a system with its own rules, logic and constraints. Specifically in the arena of political development, historians found fruitful the notion of "political culture," which allowed them to apply the notion of culture as a malleable but powerful system that sets the parameters within which political life can be enacted. Gender theory also provided productive ways to analyze the workings of society and politics as a whole, not just introducing the study of women as a footnote to male dominated history but subjecting the fundamental organizing principles of society to new questions. ${ }^{4}$

This laundry list of theoretical inspirations and influences on American historiography since the 1980s could no doubt be expanded and refined, but it will have to serve as a rough guide to the intellectual context in which American historians of Muscovy, as of other states and regions, have worked for the last twenty years. Few Muscovite historians acknowledge the direct influence of theory on their work, but the intellectual environment nonetheless nudges the field in certain directions, heightening the interest and timeliness of certain kinds of questions, suggesting particular approaches. The influences are seen in a general and striking shift in the kinds of questions addressed.

Over the last two decades, the works of American historians of early Russia have demonstrated an on-going interest in understanding the means that the state used to win the allegiance and acceptance of its subject populations. Many of us have turned our attention to what Nancy Shields Kollmann calls "strategies of integration," or the ideological and practical mechanisms by which the grand princely and later the tsarist state pulled a dispersed population into a more or less consensual union, united by belief in the legitimacy of a ruling system. This vision of a successful project of legitimation sets recent work apart from earlier scholarship, most of which assumed that the Muscovite ruler exercised his power in an unmediated fashion, without consideration of the wishes of the ruled. Much of

4. Antonio Gramsci, Selections from the Prison Notebooks of Antonio Gramsci; edited and translated by Quintin Hoare and Geoffrey Nowell Smith (London: Lawrence \& Wishart, 1971); Jürgen Habermas first reached readers of English with a pithy statement of his basic ideas in 1974: "The Public Sphere: An Encyclopedia Article (1964)," New German Critique, 3 (1974): 49-55. This was followed by the publication of a translation of his book in 1989: The Structural Transformation of the Public Sphere: An Inquiry into a Category of Bourgeois Society, translated by Thomas Burger with Frederick Lawrence (Cambridge, Mass.: MIT Press, 1989). Michel Foucault, The Archeology of Knowledge (London: Tavistock Publications, 1972); and idem, Discipline and Punish: The Birth of the Prison (New York: Pantheon Books, 1977). Norbert Elias, The Civilizing Process, 2 vols., trans. by Edmund Jephcott (New York : Urizen Books, 1978). Clifford Geertz, The Interpretation of Cultures: Selected Essays (New York: Basic Books, 1973). On political culture, see for example, The French Revolution and the Creation of Modern Political Culture, 4 vols., ed. by Keith Michael Baker (Oxford - New York: Pergamon Press, 1987). For a influential early statement of the productivity of gender analysis, see Joan W. Scott, "Gender: A Useful Category of Historical Analysis," The American Historical Review, 91:5 (1986): 1053-1075. 
the older work argued that through their control of all land and resources and the elimination of local power bases, Muscovite rulers from the late fifteenth century on managed to subjugate their population in an absolute fashion. To the extent that these works treated ideological aspects of political life, they generally rested on the strong but unexamined assertion that Russian Orthodoxy provided a theological basis for absolute rule and the Church reinforced a culture of passivity and endurance.

With a few notable exceptions, in the field overall there has been a decided movement away from dwelling exclusively or extensively on the coercive violence of the Muscovite state and passivity of its population, toward the other ways in which the state managed to extend its shallow control over a vast land. ${ }^{5}$ But because Muscovite rulers did not succeed in extending that control or integrating its population under a carefully structured claim of legitimacy until the mid-sixteenth century, these questions cannot be posed for the earlier centuries. Not only do the sources necessary to support such an inquiry not survive for the late medieval period, but they could not have been produced in the first place until the state's ambitions swelled and the effort to create a plausible, popular basis for tsarist legitimacy began. Although medieval comparisons continue to surface in studies of sixteenthand seventeenth-century Muscovy, the broader state project of integration, assimilation, and inclusion of the popular community was a distinctly early modern one. ${ }^{6}$ Hence with the adoption of an expanded conception of state-building as a broader process that includes what goes on outside of the state narrowly defined, US historical work has necessarily shifted its focus forward in time. And it is here that US historiography is liveliest, and has produced the most fire and sparks.

Within Muscovite historiography itself, the shift toward culture as a defining actor could be traced to a number of different scholars. James Billington's spiritual approach or Richard Pipes' patrimonial model, for instance, offer two starting places for change within American historiography. Pipes famously described a tsar who ruled his realm as his household writ large, in the fashion of a Roman-style paterfamilias with unlimited rights over his wife, children, and dependents, but the model has proved generative of divergent applications. Pipes' Russia under the Old Regime contributed to a move to consider the possible alternative meanings of patrimonialism in a more anthropological sense, and to ponder the meaning of kinship and family as important political factors in a Muscovite court where formal

5. Important exceptions to this pattern include: Richard Hellie, "Why Did the Muscovite Elite Not Rebel?" Russian History, 25 (1998): 155-162; and idem, "Thoughts on the Absence of Elite Resistance in Muscovy," Kritika: Explorations in Russian and Eurasian History, 1:1 (2000): 5-20; Marshall Poe, "A People Born to Slavery": Russia in Early Modern European Ethnography, 1476-1748 (Ithaca, NY: Cornell University Press, 2000); and idem, "Ex tempore: Muscovite Despotism: The Truth About Muscovy," Kritika: Explorations in Russian and Eurasian History, 3:3 (2002): 473-486.

6. Daniel B. Rowland, "Ivan the Terrible as a Carolingian Renaissance Prince," Harvard Ukrainian Studies, 19 (1995): 594-606; Isolde Thyrêt, Between God and Tsar: Religious Symbolism and the Royal Women of Muscovite Russia (DeKalb, IL: Northern Illinois University Press, 2001). 
institutions were only weakly developed. ${ }^{7}$ His strong statements about the defining role of the absence of private property in shaping Russia's autocratic political culture have taken on emblematic importance as fundamental axioms for some, and as profound misinterpretations in urgent need of correction for others. ${ }^{8}$

As the key figures in shifting the balance of the field, however, I would identify Michael Cherniavsky and Edward Keenan. Cherniavsky, in his numerous provocative essays and his wonderful book, Tsar and People, illuminated the particularities of Muscovite political culture, steeped in Orthodoxy theology and steppe politics, and attempted to broaden his cast of political actors to include ordinary Russian people, not just the tsar and his advisers. Keenan, in his extraordinarily influential essay, "Muscovite Political Folkways," explicitly set himself the task of outlining the unstated general governing rules of Muscovite political life, which, he asserted, applied in equal measure to tsars and their elites and to peasants in their communes. ${ }^{9}$ Following these two luminaries and other, more eclectic lights, the field has burgeoned in recent years. Many of the same people who were active in establishing the outlines of institutional development twenty years ago have shifted their own interests, working on Muscovite political, religious, legal, and social culture and practices.

One can perhaps identify three thematic clusters within these culturally oriented studies. The first explores the meanings and messages imbedded in the rituals, homilies, chronicles, pilgrimages, iconography, and architectural ensembles through which the regime represented itself to the people. These interdisciplinary readings of often non-textual sources are characterized by a willingness to take seriously not only the pragmatic, expedient lessons deliberately served up by political propagandists, but also the more double-edged theological and moral content. ${ }^{10}$ A second set of works builds out from the findings of the first, testing the

7. Nancy Shields Kollmann, Kinship and Politics: The Making of the Muscovite Political System, 1345-1547 (Stanford: Stanford University Press, 1987); Robert O. Crummey, Aristocrats and Servitors: The Boyar Elite in Russia, 1613-1689 (Princeton: Princeton University Press, 1983); Ann M. Kleimola, "The Canonization of Tsarevich Dmitrii: A Kinship of Interests," Russian History/Histoire Russe, 25:1-2 (1998): 107-117.

8. Richard Pipes, Russia under the Old Regime, op. cit.; and his Property and Freedom (New York: Alfred A. Knopf, 1999); R. Hellie ("Thoughts...," art. cit.) is one of his supporters. For one of his critics, see George G. Weickhardt, "The Pre-Petrine Law of Property," Slavic Review, 52 (1993): 663-679; and Richard Pipes, "Response: Was There Private Property in Muscovite Russia?" Slavic Review, 53 (1994): 524-538.

9. James H. Billington, The Icon and the Axe: An Interpretive History of Russian Culture (New York: Knopf, 1966); Michael Cherniavsky, "Holy Russia: A Study in the History of an Idea," American Historical Review, 63 (1958): 617-637; idem, "The Old Believers and the New Religion," Slavic Review, 25 (1966): 1-39; idem, Tsar and People: Studies in Russian Myths (New Haven: Yale University Press, 1961); Edward L. Keenan, "Muscovite Political Folkways," Russian Review, 45 (1986): 115-181.

10. Among others, see Michael S. Flier, "Court Ceremony in an Age of Reform: Patriarch Nikon and the Palm Sunday Ritual," in Samuel H. Baron and Nancy Shields Kollmann, eds., Religion and Culture in Early Modern Russia and Ukraine (DeKalb: Northern University Press, 1997): 73-95; and his "Filling in the Blanks: The Church of the Intercession and the Architecture of Medieval Muscovite Ritual," Harvard Ukrainian Studies, 19 (1995): 120137; David Goldfrank, "Aristotle, Bodin, Montesquieu to the Rescue: Making Sense of the 
extent to which various segments of the population understood, internalized, accepted, rejected, or made use of officially broadcast ideologies.$^{11}$ Finally, a third catch-all group may be characterized as studies of Muscovite social practices and spiritual culture in settings not directly associated with the sphere of politics and the state. These works aim to identify the fundamental moral assumptions and ways of structuring lives that shaped Muscovite thought and practice. In this category we may place works ranging from Daniel Kaiser's compelling assessment of the ways in which official Orthodoxy shaped intimate, everyday behavior, to Eve Levin's supple reexamination of "dvoeverie" or dual-belief in Russian religious culture, to Georg Michels' disturbing descriptions of the abusive conduct of church hierarchs. ${ }^{12}$ Moving beyond studies of political oppression or of tsarist propaganda,

Despotism Issue," Forschungen zur osteuropäischen Geschichte, 58 (2002); Priscilla Hunt, "Ivan IV's Personal Mythology of Kingship," Slavic Review, 52 (1993): 769-809; David B. Miller, "Creating Legitimacy: Ritual, Ideology, and Power in Sixteenth-Century Russia," Russian History, 21 (1994): 289-315; and his "The Cult of Saint Sergius of Radonezh and Its Political Uses," Slavic Review, 52 (1993): 680-699; Daniel B. Rowland, "Biblical Military Imagery in the Political Culture of Early Modern Russia: The Blessed Host of the Heavenly Tsar," in Michael S. Flier and Daniel B. Rowland, eds., Medieval Russian Culture, vol. 2 (Berkeley: University of California Press, 1994) : 182-212; and his "Boris Godunov's Uses of Architecture, 1584-1605," in James Cracraft and Daniel Rowland, eds., Architectures of Russian Identity, 1500 to the Present (Chicago: University of Chicago Press, 2003). An excellent summary of the work on pre-petrine representations of tsarist authority is: Richard S. Wortman, Scenarios of Power: Myth and Ceremony in Russian Monarchy, vol. 1: From Peter the Great to the Death of Nicholas I (Princeton, N.J.: Princeton University Press, 1995). Works on representations of power were not new in the 1990s. Important earlier contributions include Paul Bushkovitch, "The Epiphany Ceremony of the Russian Court in the Sixteenth and Seventeenth Centuries," Russian Review, 49 (1990): 1-18; Robert O. Crummey, "Court Spectacles in Seventeenth-Century Russia: Illusion and Reality," in Essays in Honor of A. A. Zimin (Columbus, Ohio: Slavica, 1985): 130-158; Daniel H. Kaiser, "Symbol and Ritual in the Marriages of Ivan IV," Russian History, (1987): 247-262; George P. Majeska, "The Moscow Coronation of 1498 Reconsidered," Jahrbücher für Geschichte Osteuropas, 26:3 (1978): 353-361; David B. Miller, "The Coronation of Ivan IV of Moscow," ibid., 15 (1967): 559-574; and his "The Velikie Minei Chetii and the Stepennaia Kniga of Metropolitan Makarii and the Origins of Russian National Consciousness," Forschungen zur osteuropäischen Geschichte, 26 (1979): 263-382.

11. Michael S. Flier, "Till the End of Time: The Apocalypse in Russian Historical Experience before 1500," in Valerie A. Kivelson and Robert H. Green, eds., Orthodox Russia: Belief and Practice under the Tsars (University Park, PA: Pennsylvania State University Press, 2003): 127-158; Valerie A. Kivelson, "Cartography, Autocracy and State Powerlessness: The Uses of Maps in Early Modern Russia," Imago Mundi, 51 (1999): 83-105; and "Muscovite Citizenship': Rights without Freedom,” Journal of Modern History, 74:3 (2002): 465-489; Nancy Shields Kollmann, "Concepts of Society and Social Identity in Early Modern Russia," in S. H. Baron and N. S. Kollmann, eds., Religion and Culture..., op. cit., and her "Pilgrimage, Procession, and Symbolic Space in Sixteenth-Century Russian Politics," in M. S. Flier and Daniel B. Rowland, eds., Medieval Russian Culture, op. cit., vol. 2: 163-181; Gail Lenhoff, Early Russian Hagiography: The Lives of Prince Fedor the Black (Wiesbaden: Harrassowitz, 1997); Marshall Poe, "What Did Russians Mean When They Called Themselves 'Slaves of the Tsar'?” Slavic Review, 57 (1998): 585-608; Isolde Thyrêt, Between God and Tsar, op. cit.

12. Daniel H. Kaiser, "Discovering Individualism Among the Deceased: Gravestones in Early Modern Russia," in J. Kotilaine and M. Poe, eds., Modernizing Muscovy, op. cit.: 433-460; idem, "Quotidian Orthodoxy: Domestic Life in Early Modern Russia," in V. A. Kivelson and R. H. Greene, eds., Orthodox Russia, op. cit.: 179-192; and his " 'Whose Wife Will She Be at the Resurrection?' Marriage and Remarriage in Early Modern Russia," Slavic Review, 62:2 (2003): 302-323; Eve Levin, "Dvoeverie and Popular Religion," in Stephen K. Batalden, ed., 
these works examine the ideologies of Muscovy in practice, as expressed by the men and women who lived in the tsar's dominion, who sued each other in the tsar's courts, who turned to the tsar to uphold their sense of honor and worth, who demanded protection when they felt their rights and entitlements were infringed upon, who rioted in protest of what they perceived as violations of proper, pious, and legitimate rule. In an innovative study, Daniel Rowland even explores various misappropriations of official ideological work as he ponders the ways in which uneducated military servicemen may have misconstrued messages carefully infused into the fresco cycles that ornamented the Golden Palace of the Tsars in the Moscow Kremlin. ${ }^{13}$

The single unifying characteristic of these works is an assumption that Muscovite rulers coopted at least certain segments of their population into a single system of values and expectations. How long the particular Muscovite formulation of political-theology held sway (into the second half of the seventeenth century, through the reign of Peter the Great or beyond) remains subject to debate. ${ }^{14}$ Also subject to debate is how far that net of ideological integration and the acceptance of tsarist legitimacy extended into society. Did peasants believe in the tsar's legitimacy? How did Cossacks, Tatars, or Kalmyks fit into the program? Several studies of riots and rebellions in the seventeenth century suggest that a broad swathe of the population had internalized the theologically informed messages of tsarist piety, mercy, and justice propagated by the tsar and his spin-masters and were willing to hold the tsar up to the standards that he himself claimed to embody. On the other hand, other scholars argue that the tsar and the privileged elites sealed

Seeking God: The Recovery of Religious Identity in Orthodox Russia, Ukraine and Georgia (DeKalb, Ill.: Northern Illinois University Press, 1993): 29-52; and her "The Administration of Western Medicine in Seventeenth-Century Russia," in J. Kotilaine and M. Poe, eds., Modernizing Muscovy, op. cit.: 363-390; Georg Michels, "Ruling without Mercy: Seventeenth-Century Russian Bishops and their Officials," Kritika: Explorations in Russian and Eurasian History, 4:3 (2003): 515-542; and his "The Rise and Fall of Archbishop Stefan: Church Power, Local Society, and the Kremlin during the Seventeenth Century," Forschungen zur osteuropäischen Geschichte, 56 (2000): 203-226; See also, Maria Salomon Arel, "Masters in Their Own House: The Russian Merchant Elite and Complaints against the English in the First Half of the Seventeenth Century," Slavonic and East European Review, 77:3 (1999): 401447; David A. Frick, "Misrepresentations, Misunderstandings, and Silences: Problems of Seventeenth-Century Ruthenian and Muscovite Cultural History," in S. H. Baron and N. S. Kollmann, eds., Religion and Culture..., op. cit.: 149-168; Valerie Kivelson, "The Souls of the Righteous in a Bright Place: Landscape and Orthodoxy in Seventeenth-Century Russian Maps," Russian Review, 58 (January 1999): 1-25; Cathy J. Potter, "Payment, Gift or Bribe? Exploring the Boundaries in Early Modern Russia," in S. Locell, A. Lebedeva, and A. Rogachevskii, eds., Bribery and Blat in Russia: Negotiating Reciprocity from the Early Modern Period to the 1990s (London: SSEES-McMillan, 2000); and her "Russian Orthodoxy and National Identity in the Seventeenth Century," Historia, 2 (1996): 121-141; Isolde Thyrêt, "Women and the Orthodox Faith in Muscovite Russia: Spiritual Experience and Practice," in V. A. Kivelson and R. H. Greene, eds., Orthodox Russia, op. cit.: 159-175.

13. Daniel Rowland, "Two Cultures, One Throne Room: Secular Courtiers and Orthodox Culture in the Golden Hall of the Moscow Kremlin," in V. A. Kivelson and R. H. Greene, eds., Orthodox Russia, op. cit.: 33-58.

14. Paul Bushkovitch, "Cultural Change among the Russian Boyars 1650-1680. New Sources and Old Problems," Forschungen zur osteuropäischen Geschichte, 56 (2000): 91-112. 
a sinister pact, welding themselves together irrevocably as a unified ruling class with a common interest in enserfing the peasantry and excluding the latter altogether from the political consensus. ${ }^{15}$ In either case, the presumption that a hegemonic set of cultural rules and values underlay Muscovite rule informs the work; it is the limits to those rules and values that remains hazy. So far, few scholars have ventured to test the responses of non-Russians and non-Orthodox to the ideological or institutional impositions of the Muscovite state. Only Michael Khodarkovsky, with his unusual linguistic range, and Janet Martin, with her statistical and economic arsenal, have tackled this subject extensively in studies of Moscow's relations with the steppe people, but a number of people have been working on Ukraine and the Cossacks, and, encouragingly, several younger historians are now entering this field. ${ }^{16}$

The research trajectories of several individual scholars illustrate these trends over time. Charles Halperin, who inaugurated his research career with important work on the influence of the Mongols on Moscow's rise, has now moved forward in time and is working primarily on the reign of Ivan IV.${ }^{17}$ Donald Ostrowski's early work on early sixteenth-century Church councils and polemics has been followed by lively comparative explorations of cultural currents in political thought and behavior, reaching to the end of the eighteenth century. ${ }^{18}$ Nancy Kollmann's work also traces very much the path outlined here. Her publications move from a study of state-building in precisely the period of interest in this volume to a broad-based

15. For various assessments, see Chester S. L. Dunning, Russia's First Civil War: The Time of Troubles and the Founding of the Romanov Dynasty (University Park, Penn: Pennsylvania State University Press, 2001); Valerie Kivelson, "Bitter Slavery and Pious Servitude: Freedom and Its Critics in Muscovite Russia," Forschungen zur osteuropäischen Geschichte, 58 (2001): 109-119; Donald Ostrowski, "The Facade of Legitimacy: Exchange of Power and Authority in Early Modern Russia,” Comparative Studies in Society and History, 44:3 (2002): 534-563.

16. Michael Khodarkovsky, Russia's Steppe Frontier: The Making of a Colonial Empire, 15001800 (Bloomington - Indianapolis: Indiana University Press, 2002); Janet Martin, "Multiethnicity in Muscovy: A Consideration of Christian and Muslim Tatars in the 1550s1580s," Journal of Early Modern History, 5:1 (2001): 1-23. On Ukraine the literature is large. Among others, see: Zenon E. Kohut, "A Dynastic or Ethno-Dynastic Tsardom? Two Early Modern Concepts of Russia," in Marsha Siefert, ed., Extending the Borders of Russian History: Essays in Honor of Alfred J. Rieber (London: Central European University Press, 2003); Serhii Plokhy, The Cossacks and Religion in Early Modern Ukraine (New York: Oxford University Press, 2001). Among younger scholars, Brian James Boeck, "Shifting Boundaries on the Don Steppe Frontier: Cossacks, Empires and Nomads to 1739," Ph.D. diss., Harvard University, 2002; Matthew Paul Romaniello, "Absolutism and Empire: Governance on Russia's Earlymodern Frontier,” Ph.D. diss., Ohio State University, 2003.

17. Halperin already was very sensitive to the importance of culture in political institutions in his 1985 study. Charles J. Halperin, Russia and the Golden Horde: The Mongol Impact on Medieval Russian History (Bloomington: University of Indiana Press, 1985); "Ivan IV and Chinggis Khan," Jahrbücher für Geschichte Osteuropas, 51:4 (2003): 481-497; "Muscovy as a Hypertrophic State: A Critique," Kritika: Explorations in Russian and Eurasian History, 3:3 (2002): 501-507.

18. Edward L. Keenan and Donald G. Ostrowski, eds., The Council of 1503: Source Studies and Questions of Ecclesiastical Landowning in Sixteenth-Century Muscovy (Cambridge, Mass.: Kritika, 1977); D. Ostrowski, Muscovy and the Mongols: Cross-cultural Influences on the Steppe Frontier, 1304-1589 (Cambridge, UK: Cambridge University Press, 1998); idem, "The Facade of Legitimacy," art. cit. 
examination of the ways in which the state and its subjects participated in a common project of mutual benefit. Her path-breaking first book treats the formation and inner workings of the Muscovite regime from the fourteenth through mid-sixteenth century. She finds that the Muscovite court functioned effectively through the efforts of a consensual ruling oligarchy of boyar families, competing among themselves but playing according to an established and shared set of rules. Kollmann's extraordinary second book moves out of the confines of court politics and beyond the regime's top-down efforts at building legitimacy. By Honor Bound demonstrates that the law, specifically the law adjudicating matters of honor and dishonor, actively constructed a unified social body, drawing in and giving legitimacy, honor, dignity, identity, and a sense of membership to each and every subject of the tsar, from the loftiest to the most lowly. Legitimacy, in this account, flowed both ways: the regime gained legitimacy in the eyes of the people to whom it administered justice and the people gained legitimacy in their roles as members of the Muscovite society and polity. Her work contributes a valuable examination of the "strategies of integration" that the tsarist regime developed in order to build its own legitimacy, to supplement its coercive might with a consensual basis among its people. ${ }^{19}$

To achieve this kind of research goal, Kollmann and others sharing her interests need to turn to a period with enough sources to permit investigation outside the Kremlin and to illuminate ordinary Muscovite subjects' encounters with and impressions of the state. One can identify the top-down efforts to propagate an official state message in the sixteenth century, even in the first half, but such stratagems appear much more detectably in the second half of the sixteenth century. And to get beyond the state's half, beyond the ritual and imagery that the state served up for popular consumption, and to gain a handle on how "the people" responded, reacted and reworked that ritual and imagery in negotiation with state power, we need to turn to the seventeenth century. This explains, I think, why the very centuries of particular interest to this volume are receiving so little attention from American researchers today. They are silent on the very questions of most pressing interest to American culturally-oriented scholars.

Even though the particular topic within the particular chronological parameters set by the organizers of this volume seems to be languishing in desuetude, it seems fair to say that the field of Muscovite Studies is a vibrant and dynamic one in the US at the moment. In fact, it is enjoying something of a Golden Age with a relatively large number of scholars from various disciplines - History, Literature, Art History, Linguistics - engaged in a common but still happily fractious pursuit of the nature of Muscovite culture and politics. Meetings are lively, diverse, and well attended, and publication proceeds at a rapid clip. Sadly, however, the field as a whole is aging, and few young scholars appear to be joining our ranks. One hopes, 
of course, that a new generation will be drawn to the field. What their questions, models, and inspirations may be is anyone's guess.

July 2, 2004

University of Michigan

Department of History

1029 Tisch Hall

Ann Arbor MI 48109-1003

vkivelso@umich.edu 